\title{
SPATIAL HETEROGENEITY OF BURN SEVERITY AND FIRST-YEAR VEGETATION RESPONSES FOLLOWING FIRE ON SUBALPINE PLATEAUS IN YELLOWSTONE NATIONAL PARK
}

\author{
Monica G. Turner \\ Robert $\mathrm{H}$. Gardner \\ Environmental Sciences Division \\ oak Ridge National Laboratory \\ Oak Ridge
}

and

William H. Romme

Biology Department

Fort Lewis College

Durango

\section{objectives}

The 1988 fires that burned in Yellowstone National Park presented ecologists with a unique opportunity to investigate ecological responses to large-scale fires (Christensen et al. 1989, Knight and Wallace 1989). The Yellowstone fires created an extremely heterogeneous landscape in terms of both the overall burning patterns and the variable fire severity within burned areas. Large fires rarely consume the entire forest because of the influence of wind variations, topography, vegetation type, natural fire breaks, and the time of day that the fire passed through (Rowe and Scotter 1973, Wright and Heinselman 1973, Van Wagner 1983). Direct fire effects such as tree mortality and organic matter consumption are related to locally variable parameters such as moisture content (Brown et al. 1985, Peterson and Ryan 1986, Ryan et al. 1988), and fire severity and return intervals are often strongly influenced by topographic and edaphic variability (Habeck and Mutch 1973, Romme and Knight 1981, Hemstrom and Franklin 1982, Whitney 1986). Therefore, burned landscapes generally contain areas of low as well as high intensity fire, usually in a complex mosaic (Van Wagner 1983). These variable fire intensities result in a heterogeneous pattern of burn severities (effects of fire on the ecosystem), as well as islands of unburned vegetation. The influence of burn severity on plant reestablishment following fire is well documented (e.g., Lyon and Stickney 1976, Rowe and Scotter 1973, Viereck 1983, Ryan and Noste 1985), and the importance of the effects of limited burns and low-intensity fires on the 
vegetation mosaic has been recognized (Habeck and Mutch 1973, Rowe 1983). However, few studies have dealt explicitly with the spatial variation of fire effects in a systematic and quantitative way.

We initiated field studies in 1989 at three sites located on subalpine plateaus in Yellowstone Park to quantify the spatial heterogeneity of the 1988 fires and the first-year responses of the vegetation. Our set of permanent plots is one of only three that were initiated on the forested plateaus during the first year following fire and is the only study that covers a relatively large spatial extent $(1 \mathrm{~km} \times 1 \mathrm{~km})$. The most rapid changes in vegetation probably will occur during the first 10 years, with a gradually slowing rate of change thereafter. In this report, we discuss the spatial heterogeneity of burn severity and the first-year responses of the vegetation in our three study areas.

\section{Methods}

Three sites were selected for study based on geological substrate and elevation and burn heterogeneity as observed aerially and from the ground. The two most important environmental gradients controlling vegetation on the plateaus are related to elevation and geological substrate (Despain in press), and our study areas were related to these gradients as follows:

1. Mystic Falls Site (1 $\mathrm{km}$ west of Biscuit Basin, north of the Little Firehole Meadows trail). Located on rhyolite substrates below $2500 \mathrm{~m}$ elevation, this combination represents the dry and infertile end of the major gradients (Despain in press) ;

2. Mallard Lake Site ( $1 \mathrm{~km}$ west of old Faithful, north of the Mallard Lake trail). Also located on rhyolite substrates but above $2500 \mathrm{~m}$ elevation, this site is more mesic than lower-elevation sites but still relatively infertile; and

3. Heart Lake Site $(1.5 \mathrm{~km}$ east of Heart Lake trailhead, north of the trail). Located in lake bed sediments and unsorted glacial deposits, this site appears more mesic and fertile than the other two on rhyolite substrates.

Because we were interested in spatial heterogeneity, study sites were purposefully placed in areas in which a mosaic of fire severity was observed. All three sites had similar pre- 
fire forest vegetation dominated by lodgepole pine (Pinus contorta var. latifolia).

Sampling was conducted during July 1989. At each site, a $1 \mathrm{~km}$ $\mathrm{x} 1 \mathrm{~km}$ grid was established in which sampling locations were located at $100 \mathrm{~m}$ intervals. Thus, there were 100 sampling points in each grid, providing a spatial resolution of 1 ha. Each grid was oriented toward true north so that our data would be compatible with remotely sensed imagery and other data stored in the park's geographic information system (GIS).

Four burn severity categories were used to classify the effects of the fires (Table 1). At each of the 100 points, we recorded information on several parameters of fire severity (severity class, depth of ash, depth to which soil was charred, and percent mineral soil exposed), pre-fire community structure (forest successional stage; tree density; tree species; and tree size, measured by diameter at breast height), first-year plant responses (percent cover of graminoids, forbs, and low shrubs; dominant species; and number of seedlings of pinus contorta var. latifolia), and general site characteristics (slope and aspect).

\section{Results}

All burn severity classes were represented on each site (Figure 1). The depth to which soil was charred increased with fire severity, ranging from an average of $5.8 \mathrm{~mm}$ in lightly burned sites to $13.6 \mathrm{~mm}$ in sites that experienced crown fires (Table 2). Among burn severity classes, unburned sites had the highest vegetative cover in forbs $(11.7 \%)$, graminoids $(18.2 \%)$, and low shrubs $(19.5 \%)$. Total vegetative cover declined somewhat in lightly burned sites but was extremely low in moderately burned $(<10 \%)$ and crown fire sites $(<4 \%)$. The percent cover of exposed mineral soil was greatest in crown fire sites $(81.9 \%)$ and lowest in unburned sites $(4.9 \%)$.

\section{Conclusions}

our results demonstrate tremendous heterogeneity in fire severity and first-year plant responses in areas burned by the 1988 fires. We plan to continue sampling the three grids annually for at least several years, and at longer intervals thereafter. The most striking changes are expected in the first few years. 
Table 1. Classes of burn severity used to define within-patch heterogeneity.

Class Burn severity Description

0 Unburned No sign of fire effects.

1 Light burn Light surface burn; canopy trees still have green needles, although stems may be scorched; soil organic layer still largely intact, though burned in small patches.

Moderate burn

Heavier surface burn; needles on canopy trees were not consumed but are dead; pre-fire soil organic layer largely consumed, but soil covered by dead leaves fallen from the canopy after the fire.

Needles of canopy trees completely consumed by fire; soil organic layer almost entirely consumed and soil is bare with no litter. 


\section{Yellowstone National Park Study Sites}

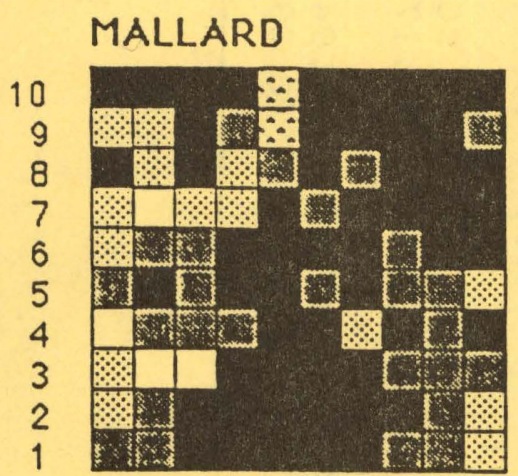

A B C DEFGH I J

\section{HEART}

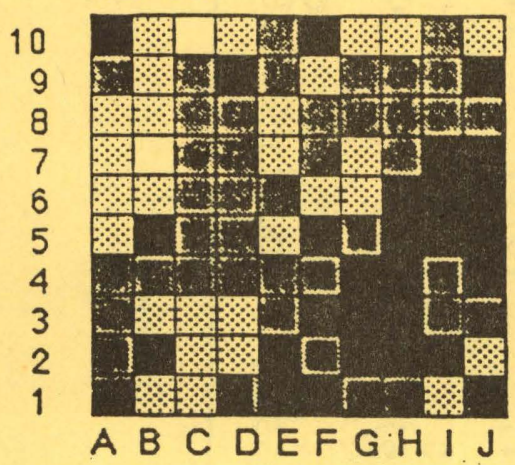

\section{MYSTIC}

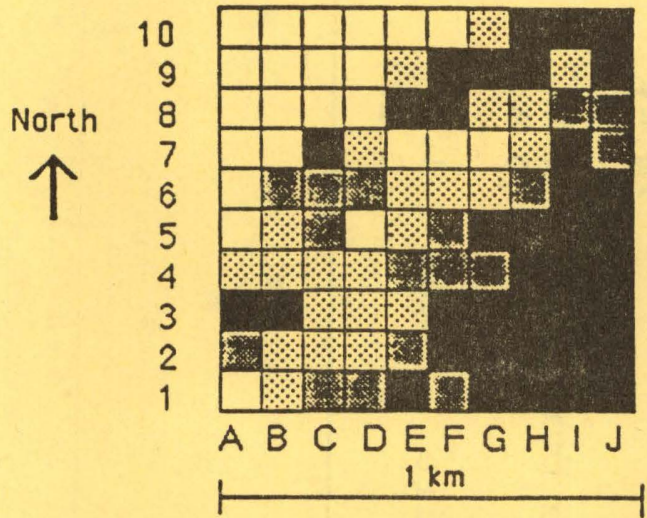

$\square$ Unburned

Light surface burn

Intense surface burn

Crown fire

Figure 1. Heterogeneity of burn severities in three $1 \mathrm{~km}$ grids that we sampled in Yellowstone during July 1989. Each grid represents 100 sampling points. The burn severity classes are described in Table 1. 


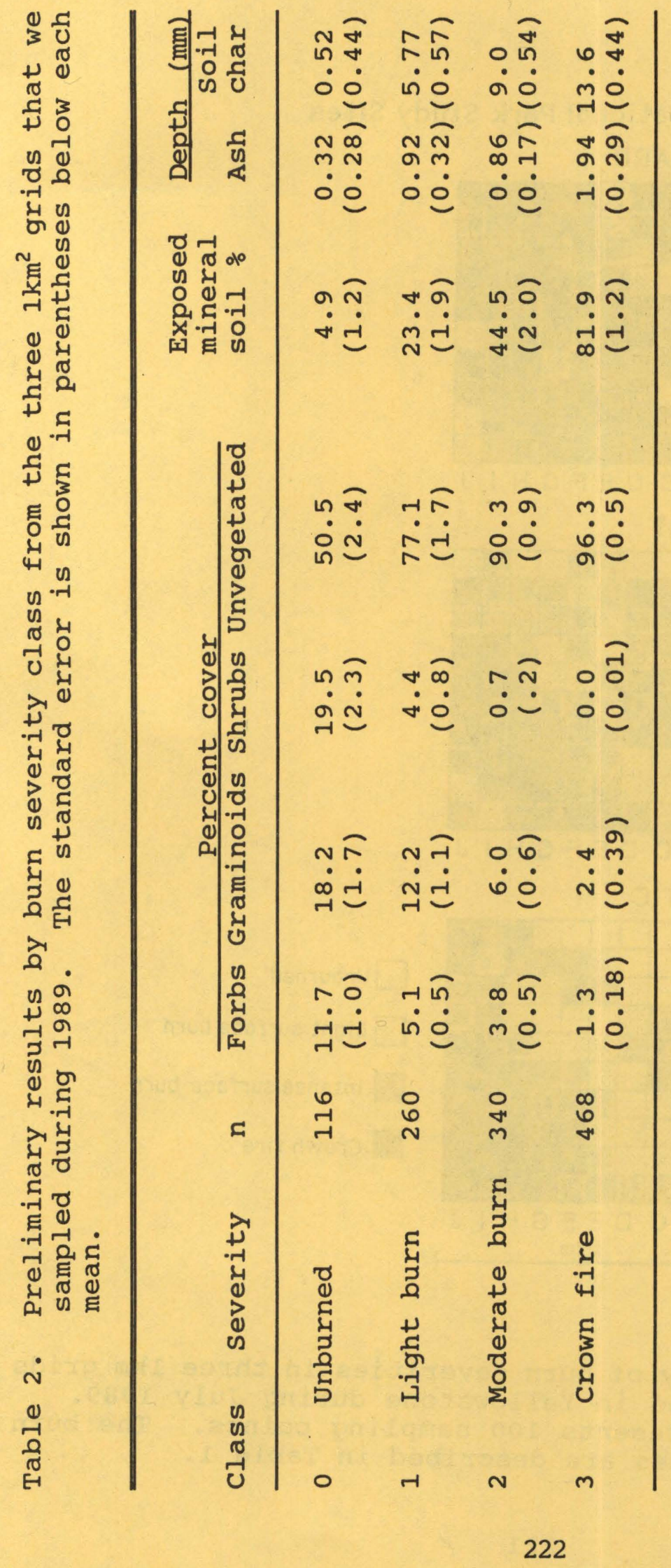


References

Brown, J. K., M. A. Marsden, K. C. Ryan and E. D. Reinhardt. 1985. Predicting duff and woody fuel consumed by prescribed fire in the norther Rocky Mountains. USDA For. Ser. Res. Paper INT-337.

Christensen, N. L., J. K. Agee, P. F. Brussard, J. Hughes, D. H. Knight, G. W. Minshall, J. M. Peek, S. J. Pyne, F. J. Swanson, J. W. Thomas, S. Wells, S. E. Williams and H. A. Wright. 1989. Interpreting the Yellowstone fires of 1988. Bioscience 39:678-685.

Despain, D. G. (In Press). Yellowstone vegetation: consequences of environment and history. Roberts Rinehart Publishing Co.

Habeck, J. R. and R. W. Mutch. 1973. Fire-dependent forests in the northern Rockies. Quat. Res. 3:408-424.

Hemstrom, M. A. and J. F. Franklin. 1982. Fire and other disturbances of the forests in Mount Rainier National Park. Quat. Res. 18:32-51.

Knight, D. H. and L. L. Wallace. 1989. The Yellowstone fires: issues in landscape ecology. Bioscience 39:700706.

Lyon, L. J. and P. F. Stickney. 1976. Early, vegetal succession following large northern Rocky Mountain wildfires. Pages 355-375 In Proceedings of the Montana Tall Timbers Fire Ecology Conference and Fire and Land Management Symposium, Number 14. Tall Timbers Research Station, Tallahassee, Florida.

Peterson, D. L. and K. C. Ryan. 1986. Modeling post-fire conifer mortality for long-range planning. Envir. Manage. 10:797-808.

Romme, W. H. and D. H. Knight. 1981. Fire frequency and subalpine forest succession along a topographic gradient in Wyoming. Ecology 62:319-326.

Rowe, J. S. 1983. Concepts of fire effects on plant species and individuals. P. 135-154 In: R. W. Wein and D. A. Maclean, eds. 1983. The role of fire in northern circumpolar ecosystems. SCOPE 18. John Wiley \& Sons, New York. 
Rowe, J. S. and G. W. Scotter. 1973. Fire in the boreal forest. Quat. Res 3:444-464.

Ryan, K. C. and N. V. Noste. 1985. Evaluating prescribed fires. Pages 230-238 In Proceedings of the Symposium and Workshop on Wilderness Fire. USDA For. Ser. Gen. Tech. Rep. INT -182 .

Ryan, K. D., D. L. Peterson and E. D. Reinhardt. 1988. Modeling long-term fire-caused mortality of Douglas-fir. Forest Science 34:190-199.

Van Wagner, C. E. 1983. Fire behavior in northern conifer forests and shrublands. Pages 65-80 In R. W. Wein and D. A. Maclean, editors. The role of fire in northern Circumpolar ecosystems. John Wiley \& Sons, New York.

Viereck, L. A. 1983. The effects of fire in black spruce ecosystems of Alaska and Northern Canada. Pp. 201-220 In: R. W. Wein and D. A. Maclean, eds. The Role of Fire in Northern Circumpolar Ecosystems. John Wiley \& Sons, New York.

Whitney, G. G. 1986. Relation of Michigan's presettlement pine forests to substrate and disturbance history. Ecology $67: 1548-1559$.

Wright, H. E., Jr. and M. L. Heinselman. 1973. Introduction to symposium on the ecological role of fire in natural coniferous forests of western and northern America. Quat. Res. 3:319-328. 